WORKING PAPER NO. 98-21/R

\title{
MEASURING HOUSING SERVICES INFLATION
}

\author{
Theodore M. Crone \\ Leonard I. Nakamura \\ Richard Voith
}

Federal Reserve Bank of Philadelphia

November 1998

Revised January 1999

The views expressed here are those of the authors and do not necessarily reflect those of the Federal Reserve Bank of Philadelphia or of the Federal Reserve System. 


\begin{abstract}

\section{MEASURING HOUSING SERVICES INFLATION}

Recent papers have questioned the accuracy of the Bureau of Labor Statistics' methodology for measuring implicit rents for owner-occupied housing. We propose cross-checking the BLS statistics by using data on owner-occupied and rental housing from the American Housing Survey.
\end{abstract}

Address correspondence to:

Leonard I. Nakamura

Research Department

Federal Reserve Bank of Philadelphia

10 Independence Mall

Philadelphia, PA 19106

215-574-3804 (office)

215-574-4364 (fax)

nakamura@frbphil.org (email) 


\section{MEASURING HOUSING SERVICES INFLATION}

\section{Introduction}

Housing services account for one-fourth of the U.S. consumer price index and oneseventh of U.S. personal consumption expenditures. Conceptually, there has long been agreement in the economics profession that the user cost of capital approach is the right one for measuring housing services. ${ }^{1}$ And since 1983 the Bureau of Labor Statistics (BLS) has used the rental equivalent method for measuring the user cost of capital. According to the BLS method, the inflation rate of rents for constant-quality rental units is used as a proxy for the inflation rate of the service flow to owner-occupied and rental housing. Recently, however, observers have questioned whether the specific methods used by the BLS to measure rents have worked well in practice (Boskin et al., 1996, Armknecht et al., 1995, Moulton, 1997). In this paper, we pose an alternative to the rental equivalent method: to estimate the implied rental rate for owner-occupied housing using hedonic regressions and estimated capitalization rates of owner-occupied housing.

There are really two nested questions about the accuracy of the rental equivalent method that we attempt to address using hedonic methods. The first is how well the methodology of the BLS measures rental price inflation itself, and the second is whether this index is also a good proxy for inflation in owner-occupied housing.

How well is rental inflation measured using the BLS survey methodology? Measuring rental inflation by survey is complicated by at least two factors: 1) the quality of a given apartment is likely to change over time either because of imperfect maintenance or through improvements made by the landlord or tenant; and 2) tenants' reports of changes in rents may be

${ }^{1}$ See Smith et al. (1988) for a discussion of the user cost of capital for owner-occupied and rental housing. 
inaccurate. ${ }^{2}$ Inaccuracies in the measured rate of rental inflation are magnified in the CPI because they are also applied to the measurement of the much larger flow of owner-occupied housing services.

Assuming rental inflation is measured accurately, is rental inflation a good proxy for the inflation rate of owner-occupied housing units? $?^{3}$ Typical owner-occupied housing units have many characteristics that differ from units designed for rental; for example, owner-occupied units are predominantly single-family detached units, while rental units are predominantly in multipleunit buildings. ${ }^{4}$ The BLS attempts to compensate for differences between the two types of units by oversampling rental units that have characteristics like those of owner-occupied housing. However, these oversampled units may not reflect typical owner-occupied units for several reasons. First, these units are often temporary rentals that drop out of the sample in a short time, so that reporting is spotty. Second, the market for these units is very thin, so that the observed rents may not be good proxies for the implicit value of the unit's service flow if it were an owneroccupied unit. Third, rental units are subject to double-sided moral hazard, which leads to longterm contracts and price regulation. Fourth, rental units are professionally managed while owneroccupied units are not.

${ }^{2}$ Issues of reporting accuracy are made more acute by the rapid turnover in rentals (Pavalone and Marshall, 1996). The useable response rates in 1995 were 79.5 percent for tenants and 64.4 percent for owner-equivalent rents; for all items in the CPI, they were 86.9 percent.

${ }^{3}$ Aside from the issues discussed below, the formulas used by the BLS for calculating inflation rates for owner-occupied housing were flawed during the period 1988-1995 (Armknecht et al.).

${ }^{4}$ Linneman and Voith (1991) show that owners and renters tend to consume systematically different housing bundles and that their valuation of the flow of housing services may differ as well. 
In this paper we develop separate price indexes for rental and owner-occupied units using hedonic methods. Using estimated capitalization rates, we then compute alternative estimates of the rate of inflation of housing services. The basic procedure is as follows. First, we estimate the value of service flow derived from each trait in the bundle of goods that we call housing services. These hedonic prices for bathrooms, basements, etc. are then used to construct constant-quality house price indexes for both rental and owner-occupied housing. ${ }^{5}$ Using techniques developed in Linneman and Voith (1991), we estimate a capitalization rate for owner-occupied housing that yields an estimate of the value of the service flow from owner-occupied housing and thus allows the construction of a price index for housing services.

Implied capitalization rates are important for measuring inflation in housing services for two reasons: 1) the capitalization rates affect the relative weights of owner-occupied and renteroccupied housing in the consumer price index; and 2) changes in capitalization rates over time change the user cost of capital and hence affect the inflation rates of owner-occupied housing services. Higher capitalization rates imply higher valuation of owner-occupied housing services, and hence, the higher the capitalization rate, the more important the owner-occupied component in the price index of housing service flows. Increases in the capitalization rates over time will increase the measured rate of inflation in owner-occupied housing services, even if the prices of housing traits from one period to the next remain unchanged. While there is little reason to expect major changes in the capitalization rate over the period we examine (1985-93), it is highly likely that capitalization rates change significantly over longer periods of time.

${ }^{5}$ Because we have data on the aggregate stock of housing traits, a useful byproduct of this analysis is that the change in the total value of rental and owner-occupied housing services over a given period can be decomposed into the price change and quantity changes. 
Using our hedonic methods we find that the measured rate of increase in the price of

owner-occupied housing services is nearly 30 percent lower than the BLS estimates. Estimates of the rate of rental inflation, on the other hand, are 12 percent higher than the BLS estimates. In addition, we find that the capitalization rates of owner-occupied housing were nearly identical in 1985 and 1993. Given our best estimate of the capitalization rate, we estimate that overall price increase of housing services for the period was 33.0 percent, an average annual rate of 3.6 percent, which is lower than the BLS estimate of 40.0 percent, an average annual rate of 4.3 percent.

The plan of the paper is as follows. Section two outlines the rental equivalent method of measuring housing services inflation used by the BLS. Section three outlines our proposed hedonic method, including the estimation of capitalization rates. Section four describes the data used in the hedonic analysis. Section five compares our measures of housing services inflation with those of the BLS. Section six concludes.

\section{The BLS Methods for Measuring Inflation in Housing Services}

Households derive a service flow from the housing stock in which they reside. In exchange for this service flow, households pay an explicit rent, or they may own the home in which they reside, in which case their rental payment is an implicit one. What we observe are rents in the first case and housing prices in the second. The BLS methodology for measuring changes in rents and the implied rent associated with owner-occupied housing has changed several times in the last quarter century.

BLS methodology prior to 1983. Prior to 1983, the BLS estimated the expenses of home 
ownership through estimates of individual cost components, such as mortgage interest costs, home purchase prices, insurance costs, and so forth. These home ownership expenses represented the cost of housing for home owners in the CPI. Home ownership expenses accounted for 14.3 percent of the CPI in December 1963, and rentals accounted for 5.5 percent of the index. Rental rates were estimated more directly. Prior to 1978, the Bureau of Labor Statistics measured rents by asking some 40,000 renters to mail rental forms back (monthly for the five largest urban areas and every three months for the other 51 urban areas sampled) giving the rental rates as of the $15^{\text {th }}$ of each reported month. Beginning in 1978, the BLS began sampling tenant units on a six-month rotation basis with 23,000 units. This slower rate of sampling takes into consideration the fact that rents typically change annually. When an apartment is sampled, its tenant is asked what the current month's rent is and what the previous month's rent had been. The two changes -- the current month change and the six-month change -- were then used to estimate the current month change in rent. ${ }^{6}$

BLS methodology after 1983. BLS adopted the concept of owners' equivalent rent for the CPI in 1983 (Gillingham and Lane, 1982). For the period from 1983-86, owners' equivalent rent was calculated by reweighting the rent sample to represent owner-occupied units. From January 1987, the BLS began sampling rental units in the same neighborhoods and with the same

${ }^{6}$ Research by the BLS found that the one-month changes tended to underestimate rent change. One reason is apparently that rent changes often occur when the tenant changes, and the new tenant may not be aware that a rent change has taken place. However, even continuousoccupancy-tenant reports of one-month changes tended to be underreported. As a consequence, beginning in January 1995, the BLS revised its method to use the six-month change in rents as an estimate of the monthly rental change. That is, it estimates the one-month change as being the sixth root of the six-month change. 
structural attributes as owner-occupied units. ${ }^{7}$ The empirical part of this paper concentrates on the eight-year change in the price of housing services between 1985 and 1993. Table 1 includes the CPI indexes for these two years and the rates of change for renters' costs, homeowners' costs, and the total cost of housing services.

The major concerns about the BLS methods center on whether changes in rental rates are measured accurately and, if they are, whether they accurately reflect changes in the user cost of capital for residents of owner-occupied housing. With respect to measuring the changes in rental rates over time, the primary concern is whether the changes in reported rents reflect pure rental inflation--holding quality constant--or whether they also reflect changes in the service flow derived from the unit. It is a well-established fact that for rental properties, age is negatively related to price. This economic depreciation can be interpreted in one of two ways: that rental properties physically depreciate over time as a result of imperfect maintenance, or that embodied technological progress makes existing rental properties economically obsolete over time. If the former is true, the economic depreciation should be reflected in an aging adjustment to the rental rate. The Bureau of Labor Statistics began applying an aging adjustment to the rental rate in $1988 .^{8}$

A potentially more serious problem is that rental homes and owner-occupied homes represent different market segments, and movements in prices of the two segments may diverge.

${ }^{7}$ Unfortunately, the rental units to which the owner-occupied units were matched were aggregated using a Sauerbeck formula, a formula that tends to cause a systematic overstatement of inflation (Armknecht et al., 1995). This overstatement is estimated by the BLS to have been about 0.5 percentage points annually. This problem was corrected in 1995 .

${ }^{8}$ In January 1988, the BLS introduced an aging adjustment with an effective overall impact of about 0.3 percentage points annually. 
With respect to the effect of a unit's age on price, for example, we show that, unlike rental properties, owner-occupied housing values are not strongly related to age. This implies that homeowners maintain their properties more fully and upgrade them to compensate for obsolescence. Thus, increases in reported rents may overstate the rate of increase of the implied rental rates of owner-occupied housing because the rental increases are for properties that are depreciating faster than owner-occupied housing.

There are differences in renter- and owner-occupied units in addition to the age-price relationship. Renter-occupied units are disproportionately in central cities, are in multifamily structures, have lower income residents, and have faster turnover. While there is some overlap, renter- and owner-occupied units are concentrated in different segments of the housing market. Increasing the sampling of rental properties that have characteristics similar to those of owneroccupied units only partially overcomes the market segmentation problem. Changes in tax treatments, financial innovations, rent control regulation, and the implicit as well as explicit contracts that define the relationship between tenants and landlords, therefore, can all affect the relationship between rentals and owner-occupied implicit rentals. Thus, over any given period, the implied rental flow of owner-occupied housing as measured by the rental changes in rental units with similar characteristics may diverge from the true underlying changes in the price of housing services because of changes in tax laws, etc.

A second problem with this methodology is the very high rate of nonresponse owing to changes in the status of the oversampled units. This occurs because the observed rental units with owner-occupied unit characteristics are often only temporary rentals and, hence, shift rapidly from rentals to owner-occupied units. This increases the difficulty of measuring rental changes over 
time and suggests that units that have owner-occupied characteristics but are temporarily rented may reflect neither the normal rental market nor the normal owner-occupied housing market. In the next section, we examine a hedonic methodology that addresses these issues.

\section{Hedonic Approach to Measuring Housing Services Inflation}

Housing is essentially a bundle of goods: kitchen, bathrooms, bedrooms, etc. There is a vast literature on hedonic techniques applied to the housing market to estimate the underlying prices of various elements of the housing bundle (see Sheppard (1998) for a review and references therein for reviews of the empirical literature). There is almost as large a literature devoted to constructing indices of house price appreciation, and many of these papers use hedonic techniques to control for changes in house quality over time (see Malpezzi, Chun and Green (1998) for a recent example). Surprisingly, there is virtually no literature using hedonic methods to construct indices of price changes of housing services. ${ }^{9}$

Estimating changes in the price of housing service flows requires estimating both the market price of constant-quality, renter- and owner-occupied housing and the capitalization rate of owner-occupied housing. Consumers make a tenure choice based on individual optimization, and the capitalization rate makes the marginal consumer indifferent between renting and owning. Along the margin of choice, inflation rates should be approximately equal, but elsewhere the inflation rates are free to diverge. Using hedonic techniques, we can identify the capitalization

${ }^{9}$ House price appreciation indexes are not indexes of the change in the flow of housing services for owner-occupied houses because they do not distinguish between gains in the value of a capital asset and changes in the underlying value of the service. In other words, house price appreciation indexes do not control for changes in the capitalization rate. 
rate that yields renter and owner indifference while statistically controlling for differences in housing unit traits.

To construct measures of changes in the price and quantity of constant-quality housing services, we estimate the market prices of the component housing traits, and using the estimates of the stock of these traits, we can estimate the change in the value of an average, constantquality house. For owner-occupied housing, a typical hedonic regression takes the form: ${ }^{10}$

$$
\operatorname{Ln} \mathrm{V}_{\text {it }}=\beta_{\mathrm{t}} \mathrm{X}_{\mathrm{it}}+\mathrm{e}_{\mathrm{it}}
$$

where: $\quad V_{i t}$ is the value of house $\mathrm{i}$ in time $\mathrm{t}$;

$\mathrm{X}_{\mathrm{i}}$ is a k element row vector of housing traits of house $\mathrm{i}$;

$B_{\mathrm{t}}$ is a vector of the estimated trait prices.

The stream of housing services, $\mathrm{S}_{\mathrm{it}}$, depends on the cost of housing $\mathrm{V}_{\mathrm{it}}$ and a capitalization rate, $\mathrm{C}_{\mathrm{it}}$, as follows:

$$
\mathrm{S}_{\mathrm{it}}=\mathrm{C}_{\mathrm{it}} \mathrm{V}_{\mathrm{it}}
$$

If $\mathrm{C}_{\mathrm{it}}$ can be estimated, then using estimates of the parameters of (1), we can construct indexes of the price of owner-occupied housing services as follows: Let $\mathrm{W}_{\mathrm{it}}=\mathrm{Z}_{\mathrm{it}}^{-1}$ where $\mathrm{Z}_{\mathrm{it}}$ is the sampling probability of house $\mathrm{i} ; \mathrm{X}_{\mathrm{ot}}$ an I by k matrix whose rows consists of values of each of the housing traits for the $\mathrm{i}^{\text {th }}$ house of the I owner-occupied houses in the sample; and $\mathrm{W}_{\mathrm{t}}$ be a 1 by I vector of weights that blows the sample up to the universe. Then $\mathrm{Q}_{\mathrm{ot}}=\mathrm{W}_{\mathrm{ot}} \mathrm{X}_{\mathrm{ot}}$ is the estimated quantity of characteristics in the universe. Then $C_{t} \exp \left(B_{t} Q_{o t}\right)$ is a measure of the nominal value of

${ }^{10}$ There is a large literature on the appropriate choice of functional form for the hedonic price function (see Linneman 1980, for example), but the simple log-linear form generally performs very well. 
rental services in period $\mathrm{t}$ in dollars of period $\mathrm{t}$. Holding the matrix of characteristics of homes constant, we can determine the price of the same bundle of services in period $t+n$ by $C_{t+n}$ $\exp \left(\mathrm{B}_{\mathrm{t}+\mathrm{n}} \mathrm{Q}_{\mathrm{ot}}\right)$.

A Laspeyres price index of rental services is then $\exp \left(B_{t+n} Q_{o t}\right) C_{t+n} / \exp \left(B_{t} Q_{o t}\right) C_{t}$. A Paasche price index of rental services is then $\exp \left(\mathrm{B}_{t+n} \mathrm{Q}_{\mathrm{ot+n}}\right) \mathrm{C}_{\mathrm{t+n}} / \exp \left(\mathrm{B}_{\mathrm{t}} \mathrm{Q}_{\mathrm{ot+n}}\right) \mathrm{C}_{\mathrm{t}}$.

We can construct a Fisher Ideal index of rental services prices as:

$\left(\left(\exp \left(B_{t+n} Q_{o t}\right) C_{t+n} / \exp \left(B_{t} Q_{o t}\right) C_{t}\right)\left(\exp \left(B_{t+n} Q_{o t+n}\right) C_{t+n} / \exp \left(B_{t} Q_{o t+n}\right) C_{t}\right)\right)^{1 / 2}$. If we are analyzing changes in owner-occupied housing only and if $\mathrm{C}_{\mathrm{t}}=\mathrm{C}$ for all $\mathrm{t}$, the capitalization rate drops out of the index and the owner-occupied house price index is a valid index for cost of housing services. The capitalization rate is, however, likely to change over time because it is a function of the user cost of capital, which in turn depends on taxes, income tax advantages of housing, mortgage rates, depreciation, rent and zoning regulations, and the expected future value of residential properties. Unfortunately, the capitalization rate $\mathrm{C}_{\mathrm{t}}$ is a scale parameter and cannot be estimated from a sample of owner-occupied units alone.

Similar indexes can be constructed for renter-occupied housing based on the corresponding hedonic regression:

$$
\operatorname{Ln}\left(\mathrm{R}_{\mathrm{jt}}\right)=?_{\mathrm{t}} \mathrm{X}_{\mathrm{jt}}+\mathrm{u}_{\mathrm{jt}}
$$

where $\quad R_{j t}$ is the rental rate of unit $j$ in time $t$, and

$?_{\mathrm{t}}$ are the estimated trait prices for rental housing.

Unlike the owner-occupied units, the capitalization rate does not appear in the index for renteroccupied units, since the service flow is observed directly.

If we are constructing an index for the total flow of housing services, it is important that 
we have an estimate of the capitalization rate for two reasons. First, the capitalization rate, as shown above, affects the measured inflation index of owner-occupied housing. Second, the capitalization rate, in part, determines the size of the service flow of owner-occupied housing relative to that of renter-occupied housing and other goods and hence its weight in the CPI. This is clear by noting that the total flow of housing services in a given year from rental housing is $\exp \left(?_{t} \mathrm{Q}_{\mathrm{rt}}\right)$ where $\mathrm{Q}_{\mathrm{rt}}$ is the quantity of rental traits and is defined analogously to $\mathrm{Q}_{\mathrm{ot}}$. Thus the total flow of housing services is the sum of the flow to owners and renters: $\exp \left(\mathrm{B}_{t} \mathrm{Q}_{\mathrm{ot}}\right) / \mathrm{C}_{\mathrm{t}}+\exp \left({ }_{t} \mathrm{Q}_{\mathrm{r}}\right)$. Note that indexes of price changes for the same bundles of housing based on this sum will depend on the capitalization rate, even if the capitalization rate is unchanged between the two periods. The Laspeyres price index of total housing services, for example, is given by $\left(\exp \left(?_{t+n} Q_{r t}\right)+C_{t+n}\right.$ $\left.\exp \left(\mathrm{B}_{\mathrm{t}+\mathrm{n}} \mathrm{Q}_{\mathrm{ot}}\right)\right) /\left(\exp \left(?_{t} \mathrm{Q}_{\mathrm{rt}}\right)+\mathrm{C}_{\mathrm{t}} \exp \left(\mathrm{B}_{\mathrm{t}} \mathrm{Q}_{\mathrm{ot}}\right)\right)$

If we assume that $\mathrm{B}_{\mathrm{t}}=$ ? , we can combine the owner and rental sample to estimate the capitalization rate as well as trait prices. ${ }^{11}$ We use owner-occupied and rental dummies to formulate the estimating equation.

$\mathrm{D}_{\mathrm{o}}=1$ if unit is owner-occupied and 0 if it is rented.

$\mathrm{D}_{\mathrm{r}}=1$ if unit is rented and 0 if it is owner-occupied.

$$
\ln \left(C_{t} V_{i t}\right) D_{o}+\ln \left(R_{j t}\right) D_{r}=B_{t} X_{l t}+e_{l t}
$$

Where:

${ }^{11}$ It is not necessary to assume that all components of B and ? are the same in order to obtain this identification. See Linneman and Voith (1991). 
$\mathrm{X}_{\mathrm{It}}$ is matrix of characteristics of homes of owners and renters;

1 runs from 1 to $\mathrm{I}+\mathrm{J}$, the total number of housing units;

$$
\ln \left(\mathrm{V}_{\mathrm{it}}\right) \mathrm{D}_{\mathrm{o}}+\ln \left(\mathrm{R}_{\mathrm{jt}}\right) \mathrm{D}_{\mathrm{r}}=-\ln \left(\mathrm{C}_{\mathrm{t}}\right) \mathrm{D}_{\mathrm{o}}+\mathrm{B}_{\mathrm{t}} \mathrm{X}_{\mathrm{lt}}+\mathrm{e}_{\mathrm{lt}}
$$

Since $V_{i t}$ is zero whenever $D_{o}$ is zero and $R_{i t}$ is zero whenever $D_{r}$ is zero, we can rewrite $3^{\prime}$ as

$$
\ln \left(\mathrm{V}_{\mathrm{it}}+\mathrm{R}_{\mathrm{jt}}\right)=\mathrm{aD}_{\mathrm{o}}+\mathrm{B}_{\mathrm{t}} \mathrm{X}_{\mathrm{lt}}+\mathrm{e}_{\mathrm{lt}}
$$

The capitalization rate $\mathrm{C}_{\mathrm{t}}=\exp (-\mathrm{a})$ can be estimated straightforwardly in the regression (3"). ${ }^{12}$ Estimating (3") separately for two time periods allows the calculation of price indexes for the total flows of housing services. In the pages that follow, we present hedonic-based estimates of price indexes for housing services based on data from the 1985 and 1993 national crosssections of the American Housing Survey and compare them to the BLS and other measures of the change in price of housing services.

\section{The American Housing Survey Data}

The American Housing Survey national cross-sections are useful for evaluating changes in the price and quantity of U.S. housing services for two reasons. First, they have data on housing

\footnotetext{
${ }^{12}$ Linneman and Voith (1991) investigate the appropriateness of pooling owners and renters.
} 
attributes, prices, and rental rates that can be used to estimate hedonic equations and capitalization rates. Second, each cross-sectional sample has associated weights that can be used to expand the sample to the housing universe. These weights allow the calculation of the total flow of housing services, given a set of estimated trait prices and capitalization rates. In addition, the data can be used to construct simpler measures of changes in the price and quantity of housing service flows, such as price per square foot or price per room of housing, that may provide useful baseline comparisons.

There are, however, a number of problems with the AHS data, one of which is missing values. Although every observation in the AHS sample has an associated weight that can be used to expand the sample to national totals, some observations have missing values for the key variables for which we wish to impute national totals, including rent, house value, and unit square footage. Other observations had missing values for particular housing traits that were used in hedonic regressions. However, one measure of housing services, number of rooms, does not have any missing values.

Truncation presents another problem in the AHS data. Rent, value, and unit square footage all have upper bounds on their values, and these upper bounds change across years. It is possible to impute values for both missing and truncated variables; the procedures are detailed in the data appendix. The variable with the most serious missing value and truncation problems was square footage. To avoid the problems with the square-foot variable, we have focused on number of rooms rather than square footage as our measure of housing size and as a simple measure of 
housing services. ${ }^{13}$ Table 2 displays the sample means and standard deviations of the variables used in the analysis for the 1985 and 1993 cross-sections. The data shown are prior to any imputations and correspond to the data used in the estimation of the hedonic equations.

\section{Changes in Simple Measures of Housing Prices and Quantities}

Using the AHS sample weights and the data on rent, value, and number of rooms, we computed simple estimates of total nominal change in the value of housing services, the change in total number of rooms of housing, and the value per room. The computations were made separately for owner- and renter-occupied housing. The change in number of rooms is a rough estimate of the change in the amount of housing services while the change in the value per room is a rough measure of the change in the value of nominal housing services resulting from the change in price of housing. ${ }^{14}$

Tables 3A and 3B show the total nominal value of housing services (row 3), total number of rooms (row 2), and value per room (row 1) for both cross-sections as well as the percent change in each measure from 1985-93. Table 3A shows the figures for owner-occupied units and Table 3B shows the same information for renter-occupied units. Thus, the third column displays the estimates of changes in total nominal value, changes in real housing services, and changes in the price of housing services on the assumption that number of rooms is a measure of housing services and that the capitalization rate for owner-occupied housing did not change between 1985

\footnotetext{
${ }^{13}$ We have also done the analysis using square footage as our primary measure of housing size and the results are qualitatively similar. In fact, the hedonic estimates are virtually identical.

${ }^{14}$ These are, of course, imperfect measures because the size and quality of rooms, as well as other attributes of the housing stock, can change over time.
} 
and 1993. The fourth column shows the official BLS data for CPI for tenants and for owners. Based on the AHS data, the nominal value of owner-occupied housing increased considerably faster (60.7 percent) than the value of renter-occupied services (45.1 percent). But the difference in growth in nominal values was almost completely due to differences in growth in quantity. The number of rooms in owner-occupied housing increased 11.2 percent, while the number of rooms in renter-occupied housing increased only 5.7 percent. The rates of price change per room were higher for owner-occupied housing units, increasing 44.5 percent compared to 37.2 percent for renter-occupied units. Both of these simple measures are slightly higher than the corresponding changes in the CPI of 41.6 percent for owner-occupied housing and 34.4 for renter-occupied units. Both our simple measures and the CPI measures suggest that owner-occupied housing prices increased substantially faster than renter-occupied prices.

\section{Hedonic Estimates of Changes in the Price and Quantity of Housing Services}

Hedonic estimates based on equations 1 and 2 suggest different changes in the prices of housing services. Table 4 presents results for the 1985 cross-section, and Table 5 presents the results for the 1993 cross-section. The estimated coefficients (trait prices) are generally of the expected signs and of reasonable magnitudes. The relative prices of individual traits are generally consistent across time periods; however, there are some important differences in trait prices between owners and renters. In particular, building age has a much larger negative impact for renters than for owners. In addition, the neighborhood variables have larger (in absolute value) and more significant values for owner-occupied units.

Using the estimated trait prices and estimated quantities of the traits, we construct 
measures of the change in the quantity of housing services keeping prices constant, constantquality changes in the price of housing services, and the total nominal change in the value of housing services. These estimates are shown in Table 6a for owner-occupied housing and Table $6 \mathrm{~b}$ for renter-occupied housing. The first column of these tables uses 1985 trait prices and quantities. In the first row of column 2, the estimates use 1985 traits but 1993 trait prices, and thus the change shown in the third column of row 1 is the constant-quality change in price. In the second row of column 2, the constant price change in housing services holds trait prices at their 1985 estimates but uses 1993 trait quantities, and, thus, the third column of the second row represents the change in housing services, holding prices constant. The row labeled "Total" uses 1993 trait prices and quantities, and, thus, the changes in the third row represent the nominal change in housing services. In column 3 , Tables $6 \mathrm{a}$ and $6 \mathrm{~b}$ report the estimates of changes in total nominal value (row 3 ), changes in real housing services (row 2), and changes in the price of housing services based on 1985 quality (row 1).

Consider, first, the owner-occupied housing. Constant-quality housing prices increased about 29.2 percent. This estimate is considerably less than the estimates based on the price per room (44.5 percent) and the CPI estimate (41.8 percent) shown in columns 3 and 4 of Table 3A. The estimated real increase in owner-occupied housing services was about 20.6, which is considerably larger than the 11.2 percent increase in the number of rooms (Table $3 \mathrm{~A}$, column 3 ). Finally, the nominal increase in the owner-occupied housing services is estimated to be 56.5 percent, which is slightly lower, but generally comparable to the 60.7 percent estimate based on nominal house prices (Table 3A, column 3).

Turning to renter-occupied housing, constant-quality rental rates increased by 38.5 
percent, which is slightly greater than the estimates for per-room foot rents in Table $3 \mathrm{~B}(37.2$ percent) and considerably higher than the CPI estimate of 34.4 percent (Table 3B, column 4). Real rental housing services rose slightly slower (4.8 percent) than rental rooms (5.7 percent). The estimated increases in the nominal value of rental services based on the hedonic method was considerably larger (45.4 percent) than the estimate based on the number of rooms (37.2 percent).

When comparing the owner-occupied and rental markets, the patterns of constant-quality price change are considerably different for the measures based on the hedonic models and the measures based on per-room prices or based on the CPI. Constant-quality house price increases estimated by the hedonic method show considerably slower increases in owner-occupied units than in rental units. This stands in stark contrast to the estimates based on the prices per room and the CPI estimates. According to the estimate of price per room or the CPI, owner-occupied housing prices increased faster than rents. In fact, according to the CPI, the value of owneroccupied units increased 22 percent faster than rents, but according to the hedonic method, price of owner-occupied housing increased 24 percent slower than rents.

\section{The Overall Changes in the Price and Quantity of Housing Services}

The rate of overall change in the price and quantity of housing services depends on what is happening in both the owner-occupied and renter-occupied markets. The weight in a price index of housing services depends not only on the number of units in each market but also on how each unit is valued. The capitalization rate, which converts the stock of owner-occupied housing to a flow of housing services, affects the relative magnitude of the owner to renter market. If capitalization rates are high, a given house value implies a greater rental stream, and thus the 
overall weight of the owner-occupied market would be greater. Similarly, lower capitalization rates would increase the relative weight of the renter-occupied market.

Table 7 shows overall housing constant-quality price indexes based on our hedonic estimates for alternative capitalization rates prevailing in each period. Along the diagonal, capitalization rates are equal across periods. Because the capitalization rate affects the relative weighting of owner and rental properties in the price index for housing services, the price index falls with capitalization as more weight is placed on the owner series, which has lower increases. The effects of weighting are relatively small; the index falls only 0.4 percentage points as the capitalization rate (in both periods) rises from 8 percent to 10 percent.

The off-diagonal elements of Table 7 represent the effects of changing capitalization rates over time as well as the weighting impacts. The effects of changes in capitalization rates over time are potentially much larger than the effects that operate through the relative weights of owners and renters in the series. A half percentage point change in the capitalization rate, say, from 9 percent in 1985 to 9.5 percent in 1993, increases the measured inflation over the eightyear period from 33.0 percent to 38.1 percent and raises the average annual inflation rate for housing services from 3.6 percent to 4.1 percent.

Table 7 implies that a good measurement of the price changes of housing services, or even the implied value of owner-occupied housing services, demands an accurate measurement of the capitalization rate for the beginning and ending period. By pooling the owners and renters, we can estimate equation (3) for each cross-section to get estimates of the capitalization rate for each 
period. ${ }^{15}$ These estimates are shown in Table 8.

The coefficients on the dummy variable for owner-occupied housing are nearly identical for both cross-sections. The coefficient of 4.905 implies an annual capitalization rate of 8.89 percent in 1985, and the coefficient of 4.900 implies a capitalization rate of 8.94 percent in 1993. Even though these coefficients are precisely estimated, they are not significantly different from one another. This implies that capitalization, except for its small effect on weighting of ownerand renter-occupied units, can essentially be ignored for the time period we examine. A 90 percent confidence interval on the capitalization rate goes from 8.73 percent to 9.05 percent for 1985. Housing service prices can rise or fall 1.6 percentage points within this range. That seems a substantial range for year-to-year inflation but does not appear to be such a substantial problem for longer term measures of inflation.

If we were to examine other periods, capitalization rates would likely be very different and, hence, have an important effect on the index of the price of housing services. For the early 1980s, when mortgage rates were well into double digits, capitalization rates are likely to be very high. For example, Linneman and Voith's estimated capitalization rates based on the 1983 AHS data only two years earlier were over 10.5 percent for the average home owner. In 1998, with long bond rates near 5 percent, capitalization rates are likely to be significantly lower than the 8.9 percent prevailing in 1993.

${ }^{15}$ Linneman and Voith show that capitalization rates may differ systematically across people, even in a given cross-section as a result of tax and life-cycle considerations. We abstract from these issues here. In addition, pooling owners and renters imposes the restriction that the trait prices are the same across samples, up to the scale of capitalization. 


\section{Conclusion}

There is general agreement that the proper measure of the cost of housing services is the user cost of capital. For rental units, the user cost of capital is the market rent. The practical issue in calculating changes in the cost of housing services for renters is to ensure that the changes refer to a constant-quality flow of housing services, and questions have been raised about whether the BLS survey of rents picks up the deterioration of the quality of housing services as rental units age. More serious questions have been raised about the calculation of price increases for owneroccupied housing services. To measure the cost of housing services for home owners, the BLS surveys rental units that are similar to owner-occupied units. The change in rents for these units is used as a measure of the change in the rental equivalent for owner-occupied units. But these units are often rented under special circumstances on a temporary basis, e.g., when the owner has moved and has not been able to sell the house. In some cases, these special circumstances may justify charging rents that are not market rents. Moreover, these units may move in and out of the BLS sample frequently as they are transferred from renter- to owner-occupied status. This makes it difficult to maintain a stable sample of these units to measure changes in the rental equivalent of owner-occupied units.

In this paper we have used standard hedonic techniques to overcome some of the problems of measuring changes in constant-quality housing services. We estimated the hedonic parameters for 1985 and 1993 on the characteristics of rental units. We used these parameters to calculate market rents for a constant-quality house in the two years and the corresponding increase in rents. According to our hedonic estimates, the cost of rental housing rose by 38.6 percent, while the BLS has estimated that it rose by 34.4 percent. This difference is consistent 
with the notion that the BLS does not fully account for the deterioration of housing services as rental units age.

Hedonic methods are even more useful for estimating changes in the cost of housing services for homeowners. Even though the BLS attempts to construct a sample of rental units that are similar to owner-occupied houses, we have listed several reasons why this sample may not yield a good estimate of the rental equivalent of owner-occupied housing. Using hedonic methods, we can estimate the market value (rather than the rental equivalent) of a constant-quality, owneroccupied house in two different periods. If the capitalization rate remains the same in both periods, the change in the value of the house can be translated directly into the change in the user cost of capital for the homeowner. Using data on rental and owner-occupied houses, we estimated that the capitalization rate remained essentially unchanged between 1985 and 1993 . Under these circumstances, our hedonic estimates imply a 29.2 percent increase in the cost of housing services for home owners. This is considerably less than the 41.8 percent increase estimated by the BLS. Given our best estimate of the capitalization rate, we estimate that overall price increase of housing services for the period was 33.0 percent, an average annual rate of 3.6 percent, which is lower than the BLS estimate of 40.0 percent, an average annual rate of 4.3 percent.

Estimates of changes in the capitalization rate are crucial for estimating changes in the cost of housing services for two reasons. First, an increase in the capitalization rate raises the cost of housing services for home owners even if the market value of constant-quality houses does not change. Second, an estimate of the capitalization rate is necessary to determine the total flow of housing services from the stock of owner-occupied houses. The combined flow of services to 
renters and home owners constitutes the total flow of housing services. And the proportions of each will determine how much rental increases and increases in the user cost of owner-occupied housing affect changes in the total cost of housing services. 


\section{Bibliography}

Armknecht, Paul A., Moulton, Brent R., and Stewart, Kenneth J., "Improvements to the Food at Home, Shelter, and Prescription Drug Indexes in the U.S. Consumer Price Index," BLS Working Paper 263, 1995.

Boskin, Michael J., E. Dulberger, R. Gordon, Z. Griliches, and D. Jorgenson, “Toward a More Accurate Measure of the Cost of Living," Final Report to the Senate Finance Committee, December 4, 1996.

Gillingham, Robert and Walter Lane," Changing the Treatment of Shelter Costs for Homeowners in the CPI," Monthly Labor Review 105, June 1982, 9-14.

Linneman, Peter, "Some Empirical Results on the Nature of the Hedonic Price Function for the Urban Housing Market," Journal of Urban Economics, 8 (1980), pp. 47-68.

Linneman, Peter, and Richard Voith, "Housing Price Functions and Ownership Capitalization Rates," Journal of Urban Economics, 30 (1991), pp. 100-111.

Malpezzi, Stephen, Gregory H. Chun and Richard K. Green, "New Place-to-Place Housing Price Indexes for U.S. Metropolitan Areas and Their Determinants," Real Estate Economics, vol. 26, pp. 235-274 (1998).

Moulton, Brent R., "Issues in Measuring Price Changes for Rent of Shelter," Paper presented at Conference on Service Sector Productivity and the Productivity Paradox, April 1997.

Pavalone, Joseph, and Sue Marshall, "Response Rates for the Consumer Price Indexes, 1995," CPI Detailed Report, January 1996, 8-14.

Sheppard, Stephen, "Hedonic Analysis of Housing Markets," Forthcoming in Handbook of Applied Economics (1998).

Smith, Lawrence B., Kenneth T. Rosen and George Fallis, "Recent Developments in Economic Models of Housing Markets," Journal of Economic Literature 26, March 1988, 162-78. 


\section{Data Appendix}

Although every observation in the AHS sample has an associated weight that can be used to expand the sample to national totals, some observations have missing values for the key variables for which we wish to impute national totals, including rent, house value, and square footage. Less crucially, other observations had missing values for particular housing traits that were used in hedonic regressions. With respect to the missing values for rent, house value, and unit square footage, we used the following simple imputation method. Since the number of rooms was available for all units, we computed the sample average ratios of rent, value, and unit square footage to number of rooms and used this ratio in conjunction with the observed number of rooms for the observation with the missing variable to impute the missing value. The imputation was done separately for owner-occupied and renter-occupied units. Table A1 summarizes the number of observations requiring imputations. The missing value problem is far more serious for rental properties, since about two-thirds of the observations required imputation of rent or unit square footage. The great majority of the units without rent data were rent- subsidized units; units missing square footage data displayed no such pattern.

In addition to missing values for rent, value, and square footage, observations had missing values on variables used in the hedonic estimations. If the missing values are not systematically correlated with the regressors, there are no special difficulties estimating the hedonic price function. However, to aggregate to the total real value of housing services, we need to have an estimate of the total stock of each trait for both cross-sections. We therefore imputed missing values.

Truncation presents another problem in the AHS data. Rent, value, and unit square 
footage all have upper bounds on their values. Unfortunately, these upper bounds change across cross-sections. Truncation is most problematic for unit square footage, the upper bound of which was decreased from 5000 square feet in 1985 to 4000 square feet in 1993, even while the median square footage of units in the sample increased over the period. As shown in Table A2, 1019 of the 1985 cross-section observations fell into the greater-than-5000-square-foot category and 1408 of the 1993 observations fell into the greater-than- 4000 category. To address the changing truncation levels, we recoded the observations in the 1985 cross-section such that all observations with value greater than 4000 were simply given a value of 4000 , as in the 1993 sample.

The truncation limits for both rent and value are less of a problem because the limits were increased from 1985-93. The maximum rent and value increased from $\$ 750$ per month and $\$ 250,000$ respectively in 1985 to $\$ 999$ and $\$ 349,999$ in 1993 . At these levels, the magnitude of the truncation problem was much smaller. As is shown in Table A2, 302 observations had reported rents greater than $\$ 750$ in 1985 , and 478 exceeded $\$ 999$ in 1993. Similarly for value, 441 exceeded the $\$ 250,0001985$ limit, and 871 exceeded the 1993 limit. The same procedure used for the unit square footage could not be employed in the case of rent and value, as this would only exacerbate the truncation problem. In the analysis that follows, the observations at the truncation level were simply assumed to have the truncation levels for rent and value. 
Table 1

U.S. Bureau of Labor Statistics Consumer Price Indexes for Housing Services (All Urban Consumers)

$\begin{array}{cc}\begin{array}{c}\text { Renters' Costs for } \\ \text { Shelter: }\end{array} & \text { Homeowners' Cost } \\ \text { for Shelter: } \\ \text { Rent, Residential } & \text { Owners' Equivalent } \\ & \text { Rent }\end{array}$

1985

1993

Percent

increase
111.8

150.3

34.4

113.2

160.5

41.8
Total: Housing Services, Shelter:

Rent and Rent Equivalent Components 
Table 2

\begin{tabular}{|c|c|c|c|c|}
\hline \multirow[b]{2}{*}{ Variable } & \multicolumn{2}{|c|}{1985} & \multicolumn{2}{|c|}{1993} \\
\hline & $\underline{\text { Mean }}$ & $\underline{\text { Std. Dev. }}$ & $\underline{\text { Mean }}$ & $\underline{\text { Std. Dev. }}$ \\
\hline Rent $^{1}$ & 340.34 & 166.14 & 473.43 & 221.01 \\
\hline Value $^{2}$ & 71835.98 & 52324.71 & 105263.95 & 79363.54 \\
\hline Owner-occupied dummy & 0.78 & 0.42 & 0.76 & 0.42 \\
\hline Multi-unit dummy & 0.15 & 0.36 & 0.16 & 0.37 \\
\hline Building age & 29.30 & 19.98 & 33.45 & 21.32 \\
\hline Number of bathrooms & 1.45 & 0.53 & 1.56 & 0.57 \\
\hline Public sewer dummy & 0.72 & 0.45 & 0.74 & 0.44 \\
\hline Central air dummy & 0.36 & 0.48 & 0.48 & 0.50 \\
\hline Holes in floor dummy & 0.01 & 0.11 & 0.01 & 0.10 \\
\hline Mice dummy & 0.04 & 0.19 & 0.02 & 0.14 \\
\hline Number of rooms & 5.84 & 1.77 & 5.91 & 1.78 \\
\hline Garage dummy & 0.64 & 0.48 & 0.67 & 0.47 \\
\hline Nonresidential use dummy & 0.02 & 0.14 & 0.02 & 0.12 \\
\hline Crime dummy & 0.04 & 0.19 & 0.06 & 0.23 \\
\hline Noise dummy & 0.07 & 0.25 & 0.07 & 0.26 \\
\hline Trash dummy & 0.07 & 0.25 & 0.05 & 0.22 \\
\hline Unit square feet & 1691.76 & 918.74 & 1723.24 & 914.34 \\
\hline Satisfaction with unit & 8.33 & 1.85 & 8.41 & 1.67 \\
\hline Satis. with neighborhood & 8.27 & 2.03 & 8.22 & 1.93 \\
\hline Midwest dummy & 0.26 & 0.44 & 0.25 & 0.43 \\
\hline South dummy & 0.35 & 0.48 & 0.36 & 0.48 \\
\hline West dummy & 0.20 & 0.40 & 0.21 & 0.41 \\
\hline
\end{tabular}

${ }^{1}$ The number of rental units for 1985 is 6493 . The number of rental units for 1993 is 7266 .

${ }^{2}$ The number of owner-occupied units is 22660 for 1985 and 23550 for 1993. Summing the owner-occupied and renter-occupied units results in a total of 29153 observations for 1985 and 30816 observations for 1993. 
Table 3A

Owner-occupied Units

$\%$ Change

Variable

$\underline{1985}$

$\underline{1993}$

$\%$ Change

in CPI

Value/Rooms

11.60

16.80

44.50

41.8

(thousands)

Rooms (millions)

347.11

386.11

11.24

Value (trillions)

4.03

6.47

60.73

Table 3B

Renter-occupied Units

Variable

$\underline{1985}$

1993

\% Change

$\%$ Change

in CPI

Rent/Rooms

77.12

105.81

37.20

34.4

Rooms (millions)

139.50

147.51

5.74

Rent (billions) 10.76

15.61

45.08 
Table 4

1985 Estimations

Intercept

Multi-unit dummy

Building age (x1000)

Number of bathrooms

Public sewer dummy

Central air dummy

Holes in floor dummy

Mice dummy

Number of rooms

Garage dummy

Nonresidential use dummy

Crime dummy 0.018

Noise dummy

Trash dummy

Satisfaction with unit

Satis. with neighborhood

Midwest dummy

South dummy

West dummy

Adjusted R ${ }^{2}$

Number of observations

$0.058^{*}$

\section{Owner-occupied $^{1}$}

$8.907^{*} \quad 0.035$

$0.224^{*} \quad 0.023$

$-0.423$

$0.329^{*}$

$0.098^{*}$

$0.166^{*}$

$-0.246^{*}$

$-0.139^{*}$

$0.117^{*}$

$0.434^{*}$

0.043

0.027

$-0.000$

$-0.049^{*}$

$0.011^{*}$

$-0.464^{*}$

$-0.393^{*}$

0.005

0.398

22660
Renter-occupied ${ }^{2}$

$5.017^{*} \quad 0.044$

$0.226^{*} \quad 0.014$

$-5.380^{*} \quad 0.330$

$0.332^{*} \quad 0.017$

$0.215^{*} \quad 0.018$

$0.161^{*} \quad 0.015$

$-0.224^{*} \quad 0.037$

$\begin{array}{ll}-0.098^{*} & 0.025\end{array}$

$0.054^{*} \quad 0.005$

$0.168^{*} \quad 0.013$

$0.051 \quad 0.044$

0.025

$\begin{array}{ll}0.015 & 0.019\end{array}$

$0.000 \quad 0.024$

$0.004 \quad 0.003$

$0.000 \quad 0.003$

$\begin{array}{ll}-0.364^{*} & 0.019\end{array}$

$-0.421^{*} \quad 0.019$

$-0.103^{*} \quad 0.020$

0.404

6493

${ }^{1}$ Dependent variable is the log of price.

${ }^{2}$ Dependent variable is the log of rent.

* Denotes significance at the $5 \%$ level 
Table 5

1993 Estimations

Intercept

Multi-unit dummy

Building age (x100)

Number of bathrooms

Public sewer dummy

Central air dummy

Holes in floor dummy

Mice dummy

Number of rooms

Garage dummy

Nonresidential use dummy

Crime dummy 0.039

0.023
Owner-occupied ${ }^{1}$

$\underline{\text { Coef }}$

$8.984^{*}$

$0.314^{*}$

$0.109^{*}$

$0.313^{*}$

$0.094^{*}$

$0.153^{*}$

$-0.343^{*}$

$-0.102^{*}$

$0.131^{*}$

$0.399^{*}$

0.033

$0.047^{*}$

0.006

$-0.107^{*}$

$0.072^{*}$

$0.017^{*}$

$-0.536^{*}$

$-0.529^{*}$

$-0.006$

0.402

23550

0.011

0.011

0.037

0.020

0.021
S.E.

0.039

0.024

0.025

0.010

0.010

0.054

0.036

0.003

0.003

0.003

0.014

0.014

0.015

Adjusted $\mathrm{R}^{2}$

Number of observations

${ }^{1}$ Dependent variable is the log of price.

${ }^{2}$ Dependent variable is the log of rent.

* Denotes significance at the 5\% level 
Table 6A

Owner-occupied Units

Variable

Constant traits (trillions)

Constant prices (trillions)

Total (trillions)

Variable

Constant traits (billions)

Constant prices (billions)

Total (billions) $\underline{1985}$

3.01

3.01

3.01

Table 6B

Renter-occupied Units

$\underline{1985}$

9.47

9.47

9.47
1993

3.89

3.63

4.71

56.48

29.24

20.60
$\%$ Change

\% Change

38.54

4.75

45.41 
Table 7

\begin{tabular}{|c|c|c|c|c|c|}
\hline \multicolumn{5}{|c|}{ Alternative Capitalization Rates and Housing Services Price Indexes: } \\
Eight Year Price Increases \\
\hline $\begin{array}{c}\text { 1985 } \\
\text { Capitalization } \\
\text { Rate }\end{array}$ & \multicolumn{5}{|c|}{1993 Capitalization Rate } \\
& \multicolumn{5}{|c|}{} \\
& $8.0 \%$ & $8.5 \%$ & $9.0 \%$ & $9.5 \%$ & $10.0 \%$ \\
\cline { 2 - 6 } & Percentage Increase in Housing Service Inflation, All Units, $1985-93$ \\
\hline $8.0 \%$ & $33.2 \%$ & $38.7 \%$ & $44.3 \%$ & $49.8 \%$ & $55.3 \%$ \\
\hline $8.5 \%$ & $27.8 \%$ & $33.1 \%$ & $38.4 \%$ & $43.7 \%$ & $49.0 \%$ \\
\hline $9.0 \%$ & $22.8 \%$ & $27.9 \%$ & $33.0 \%$ & $38.1 \%$ & $43.2 \%$ \\
\hline $9.5 \%$ & $18.1 \%$ & $23.1 \%$ & $28.0 \%$ & $32.9 \%$ & $37.8 \%$ \\
\hline $10.0 \%$ & $13.9 \%$ & $18.6 \%$ & $23.3 \%$ & $28.1 \%$ & $32.8 \%$ \\
\hline
\end{tabular}


Table 8

Pooling Owners and Renters: Estimating Capitalization Rates

\begin{tabular}{lcccc} 
& \multicolumn{2}{c}{1985} & \multicolumn{2}{c}{1993} \\
Intercept & $\underline{\text { Coef }}$ & $\underline{\text { S.E. }}$ & $\underline{\text { Coef }}$ & $\underline{\text { S.E. }}$ \\
Owner-occupied dummy & $4.272^{*}$ & 0.029 & $4.449^{*}$ & 0.031 \\
Multi-unit dummy & $4.905^{*}$ & 0.012 & $4.900^{*}$ & 0.012 \\
Building age(x100) & $0.314^{*}$ & 0.014 & $0.336^{*}$ & 0.014 \\
Number of bathrooms & $-0.155^{*}$ & 0.022 & 0.002 & 0.020 \\
Public sewer dummy & $0.338^{*}$ & 0.009 & $0.323^{*}$ & 0.009 \\
Central air dummy & $0.121^{*}$ & 0.009 & $0.121^{*}$ & 0.009 \\
Holes in floor dummy & $0.171^{*}$ & 0.009 & $0.158^{*}$ & 0.009 \\
Mice dummy & $-0.206^{*}$ & 0.035 & $-0.160^{*}$ & 0.037 \\
Number of rooms & $-0.115^{*}$ & 0.020 & $-0.055^{*}$ & 0.026 \\
Garage dummy & $0.108^{*}$ & 0.003 & $0.120^{*}$ & 0.003 \\
Nonresidential use dummy & $0.367^{*}$ & 0.009 & $0.316^{*}$ & 0.009 \\
Crime dummy & 0.032 & 0.027 & 0.028 & 0.031 \\
Noise dummy & $0.047^{*}$ & 0.021 & $0.050^{*}$ & 0.017 \\
Trash dummy & 0.013 & 0.015 & 0.017 & 0.015 \\
Satisfaction with unit & $-0.040^{*}$ & 0.015 & $-0.083^{*}$ & 0.017 \\
Satis. with neighborhood & $0.041^{*}$ & 0.002 & $0.050^{*}$ & 0.003 \\
Midwest dummy & $0.008^{*}$ & 0.002 & $0.012^{*}$ & 0.002 \\
South dummy & $-0.444^{*}$ & 0.011 & $-0.510^{*}$ & 0.012 \\
West dummy & $-0.405^{*}$ & 0.012 & $-0.534^{*}$ & 0.012 \\
Adjusted R & $-0.033^{*}$ & 0.013 & $-0.056^{*}$ & 0.013 \\
Number of observations & & & & 0.924 \\
& 0.925 & & 30816 &
\end{tabular}

${ }^{*}$ Denotes significance at the $5 \%$ level 
Table A1

\begin{tabular}{|l|c|c|c|c|}
\hline Imputed values: & 1985 Renter & 1985 Owner & 1993 Renter & 1993 Owner \\
\hline UNITSF & 4142 & 1155 & 4667 & 2289 \\
\hline RENT & 3804 & - & 3822 & - \\
\hline VALUE & - & 33 & - & 55 \\
\hline
\end{tabular}

Table A2

\begin{tabular}{|l|l|l|l|l|l|l|}
\hline & $\begin{array}{l}1985 \\
\text { Upper } \\
\text { Bound }\end{array}$ & $\begin{array}{l}1985 \\
\text { Category } \\
\text { Definition }\end{array}$ & $\begin{array}{l}\text { 1985 } \\
\text { \# of obs. } \\
\text { in category }\end{array}$ & $\begin{array}{l}\text { l993 } \\
\text { Upper } \\
\text { Bound }\end{array}$ & $\begin{array}{l}\text { l993 } \\
\text { Category } \\
\text { Definition }\end{array}$ & $\begin{array}{l}\text { 1993 } \\
\text { \# of obs. } \\
\text { in category }\end{array}$ \\
\hline UNITSF & 5001 & $>5000$ & 1019 & 4038 & $>4000$ & 1408 \\
\hline RENT & 751 & $>750$ & 302 & 1000 & $>999$ & 478 \\
\hline VALUE & 250001 & $>250000$ & 441 & 350000 & $>349999$ & 871 \\
\hline
\end{tabular}

